\title{
Occupation Pattern of a Harbor Inlet by the Estuarine Dolphin, Sotalia guianensis (P. J. Van Bénéden, 1864) (Cetacea, Delphinidae)
}

\author{
Marta Jussara Cremer ${ }^{1,2 *}$, Paulo César Simões-Lopes ${ }^{3}$ and José Salatiel Rodrigues Pires ${ }^{1}$ \\ ${ }^{1}$ Laboratório de Análise e Planejamento Ambiental; Departamento de Hidrobiologia; Universidade Federal de São \\ Carlos; São Carlos - SP - Brasil. ${ }^{2}$ Laboratório de Nectologia; Departamento de Ciências Biológicas; Universidade \\ da Região de Joinville; Joinville - SC - Brasil. ${ }^{3}$ Laboratório de Mamíferos Aquáticos; Departamento de Ecologia e \\ Zoologia; Universidade Federal de Santa Catarina; Florianópolis - SC - Brasil
}

\begin{abstract}
The occupation pattern of Sotalia guianensis in São Francisco do Sul harbor inlet, in Babitonga bay, southern Brazil, was studied between September 1996 and June 1998. A total of 200 h of naturalistic observations and 141.2 $h$ of estuarine dolphin systematic observations were made using binoculars $7 x 50$. At each three minutes interval, data about number of individuals and behavior were registered. The population used the harbor inlet intensively, mainly for fishing activities. Ebb tide was responsible for a higher occupation index. Considering the months analyzed, the higher occupation index occurred in May, and in January the lower occurrence was observed. The mean group size was four individuals.
\end{abstract}

Key words: Sotalia guianensis, occupation index, Babitonga bay, harbor use, behavior

\section{INTRODUCTION}

Studies about cetacean habitat use have confirmed the existence of core areas, or concentration areas, in the home range area of many species. In the estuarine dolphin Sotalia guianensis (P. J. Van Bénéden, 1864) this characteristic has been corroborated in many studies (Cremer, 2000; Bonin, 2001; Edwards and Schnell, 2001; Lodi, 2003; Flores and Bazzalo, 2004; Wedekin et al., in press), so as also for other cetacean species with coastal habits, like the atlantic white-sided dolphin, Lagenorhynchus acutus (Selzer and Payne, 1988) and the bottlenose dolphin, Tursiops truncatus (e. g., Wursig and Wursig, 1979;
Gubbins, 2002). In most cases, data indicated that these areas were strongly related to fishing activities, constituting key areas in the populations' home range. This becomes more evident considering the resident populations. For $S$. guianensis, these populations have been observed in recent years through the use of photo identification techniques along the Brazilian coast, such as in Guanabara bay (Rio de Janeiro) (Pizzorno, 1999), Sepetiba bay (Rio de Janeiro) (Simão et al. 2000), Cananéia estuarine complex (São Paulo) (Santos et al., 2001), Babitonga bay (Santa Catarina) (Cremer, 2000; Hardt, 2005) and Baía Norte (Santa Catarina) (Flores, 1999).

\footnotetext{
*Author for correspondence: marta.cremer@univille.net
} 
Babitonga bay has an estuarine dolphin population $S$. guianensis that show strong evidence of residence, and is being studied for at least ten years (Cremer, 2000; Hardt, 2005). Sotalia guianensis is a typical coastal specie that occurs in bays and inlets along all its distribution area. It occurs in Atlantic Ocean, in most of South America coast and part of Central America. Its distribution seems to be continuous, from Nicaragua (Carr \& Bonde, 2000) to Florianópolis, Santa Catarina, Brazil (Simões-Lopes, 1988). The present work analyzed data about habitat use pattern of this population in the São Francisco do Sul harbor inlet, in Babitonga bay. This area was considered a dolphin concentration area, although this place has suffered a strong impact resulted from harbor activities.

The knowledge about habitat use pattern and home range areas are important for improving the conservation strategies, mainly for resident populations, subsiding monitoring work and impacts evaluation (Clemmons \& Bucholz, 1997; Primack \& Rodrigues, 2001).

\section{METHODOLOGY}

\section{Study area}

The São Francisco do Sul harbor is located in Babitonga bay, south Brazilian region $\left(48^{\circ} 38^{\prime} 8^{\prime \prime} \mathrm{W} ; 26^{\circ} 14^{\prime} 5^{\prime \prime} \mathrm{S}\right.$ ) (Fig. 1). The bay comprehend an area of $160 \mathrm{~km}^{2}$, representing an important estuarine area in South Brazil. The harbor is located in the central portion of the bay, in its south margin, beside the historical city of São Francisco do Sul. It was inaugurated in 1955 and has been considered a "natural harbor", because of the presence of a deep entrance channel (with 11 meters of deep along its extension) and a natural opening channel with $1.8 \mathrm{~km}$ of width.

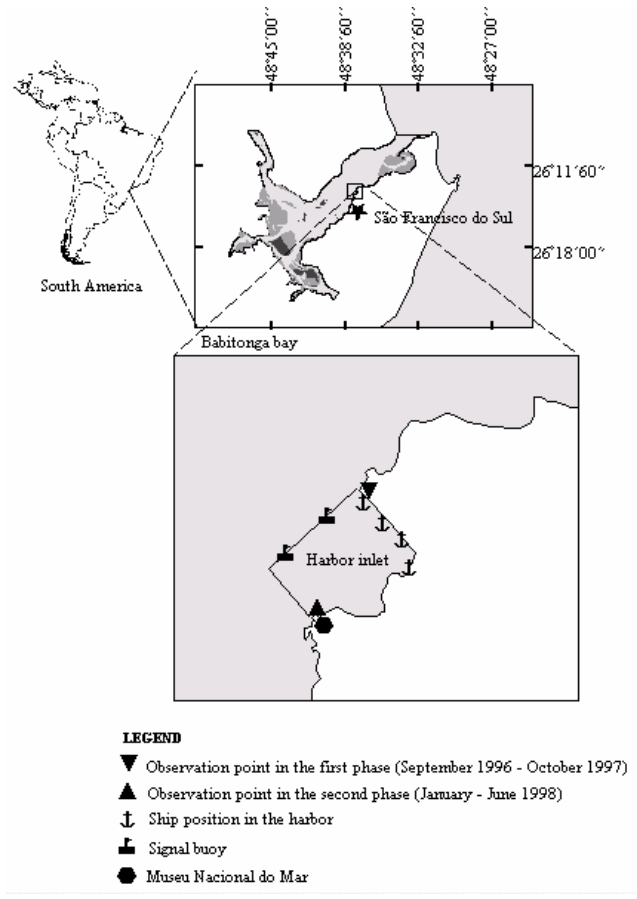

Figure 1 - São Francisco do Sul harbor inlet, located in Babitonga bay, southern Brazil (48³8'8” $\left.\mathrm{W} ; 26^{\circ} 14^{\prime} 5^{\prime \prime} \mathrm{S}\right)$.

The sampling area was defined visually, using as reference the harbor signal buoys and the anchorage of Museu do Mar (Fig. 1), corresponding to an area of around $0.24 \mathrm{~km}^{2}$. The mean depth in this area is between 8 and 11 meters, and the evolution basin is periodically dredged (two or three years interval) for the depth maintenance. This area forms an inlet known by the local people as "dolphins inlet", because of $S$. guianensis occurrence along all the year. This area 
had also intense boat traffic, including tourist boats that go there for dolphin watching.

\section{Data collection}

The observations were done in two phases, with the presence of one or two experienced observers. In the period between September 1996 and October 1997, 200 observation hours were accomplished using naturalistic methods (Altmann, 1974). In this period, the observers were positioned on the charge ships that were attracted in the harbor (Fig. 1). Because of logistic reasons for ships access, the observation point had to be changed. In this way, in the period between January and June 1998, 141.2 sampling hours from a point in the margin using binoculars $7 \times 50$ were made (Fig. 1). In this phase, the scan sampling method was used, which was adapted from Altmann (1974). Group behavior and number of individuals in the area were registered continuously for 45 minutes, with the information accumulated in each three minutes sampling periods, followed by a 15 minutes resting period. Only the behavioral states were registered because of the distance between the sampling point and the animals (maximum of 600 meters). The recording of events at this distance might produce sampling distortions, favoring more evident aerial behaviors, like jumps. The samplings were conducted from 7:00 am to $6: 00 \mathrm{pm}$, but if the environmental conditions changed, with Beaufort more than 2, the samplings were interrupted.

The behavioral states considered in this work were adapted from many authors, and four categories were defined: fishing, traveling, resting and socializing (Norris \& Dohl, 1980; Shane, 1990; Ballance, 1992; Daura-Jorge et al., 2005).

Group was defined adapted from Shane (1990) that established it as "any aggregation of dolphins in an apparent association, frequently, but not always, engaged in the same activity". For the group composition only adults and calves were differentiated. So, all animals that remained near an adult most of time and that had at least $1 / 3$ its size were considered calves.

An occupation index was calculated considering the mean number of individuals in the inlet at each hour as an indicative of intensity use. Variations in this index were analyzed considering the months (Kruskal-Wallis), tide (ebbing or flowing) (MannWhitney U test), moon phases (ANOVA) and the day periods (Kruskal-Wallis). In this case, three periods were defined: morning (7:00 am - 10:59 am); middle-day (11:00 am - 1:59 pm); and afternoon $(2: 00 \mathrm{pm}-6: 00 \mathrm{pm})$. For behavior pattern analysis, Kruskall-Wallis test was used. In this case, for the analysis we considered the number of observations of each behavior pattern per sampling day. For tide definition (ebbing or flowing) the tide-table for the port of São Francisco do Sul was used (www.mar.mil.br).

\section{RESULTS}

Considering the systemized sampling period, $94.35 \mathrm{~h}$ of direct observation of the inlet were made, distributed in 30 days with an inlet medium occupation index of $3.95( \pm 3.12)$ individuals/h along all the period.

\section{Inlet occupation}

The occupation of the inlet by the dolphins showed difference between months (Fig. 2) [H (5, $\mathrm{N}=201)=26.982 ; \mathrm{p}=0.0001<0.05]$. May was the month with highest occupation index (12.27 individuals/ $h$ ) and January was the month of lowest index (0.26 individuals/h). Along the sampling period, at only one day (in April), the dolphins did not enter in the inlet.

Inlet occupation index do not varied along the day periods $[\mathrm{H}(2, \mathrm{~N}=201)=0.547 ; \mathrm{p}=0.76>0.05]$ (Fig. 3).

Tide influenced the inlet occupation $(\mathrm{z}=2.642$; $\mathrm{p}=$ $0.008<0.05$ ) (Fig. 4). The observations indicated that the dolphins tended to enter the inlet in the beginning of the high tide and the ebb was the period of highest occupation index. The number of groups in the inlet was gradually reduced with the beginning of the low tide and in the end of the flood tide, few groups remained in the inlet.

Moon phase do not influenced the inlet occupation $\left(F_{3 ; 201}=0.7409 ; p=0.52\right)$ (Fig. 5). 


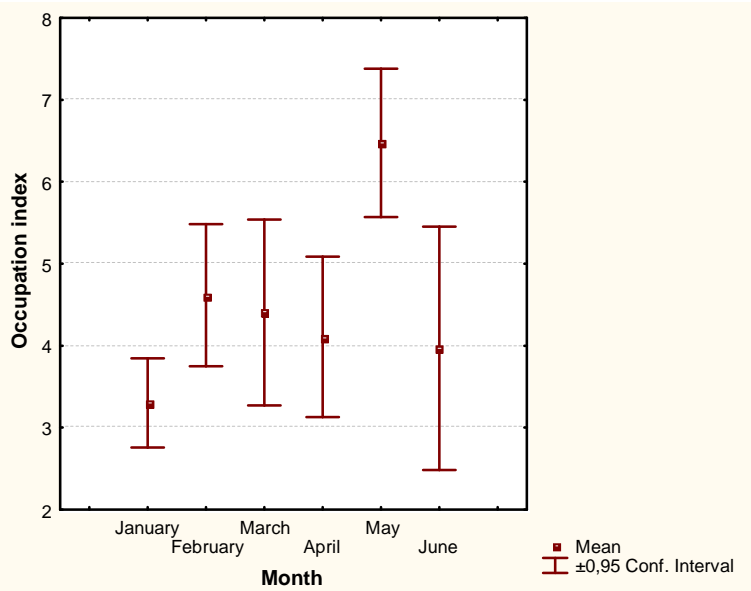

Figure 2 - Sotalia guianensis occupation index variation in São Francisco do Sul harbor inlet along the months.

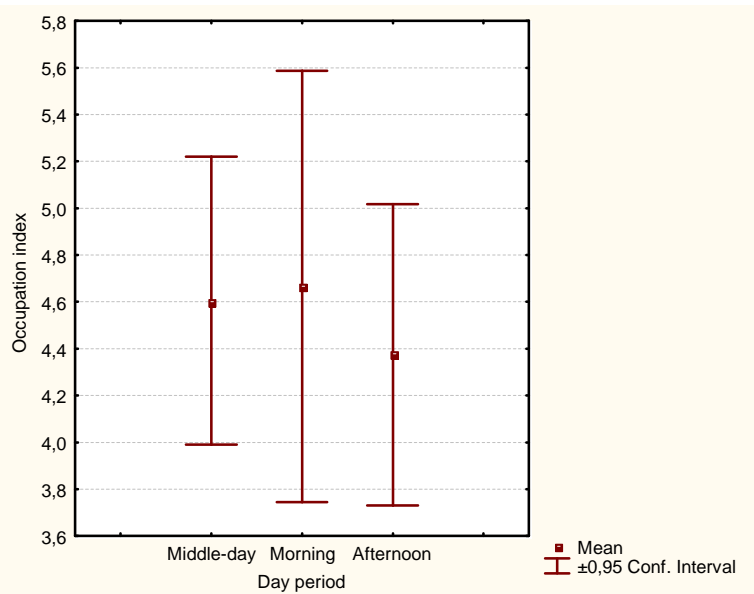

Figure 3 - Sotalia guianensis occupation index variation in São Francisco do Sul harbor inlet along the day.

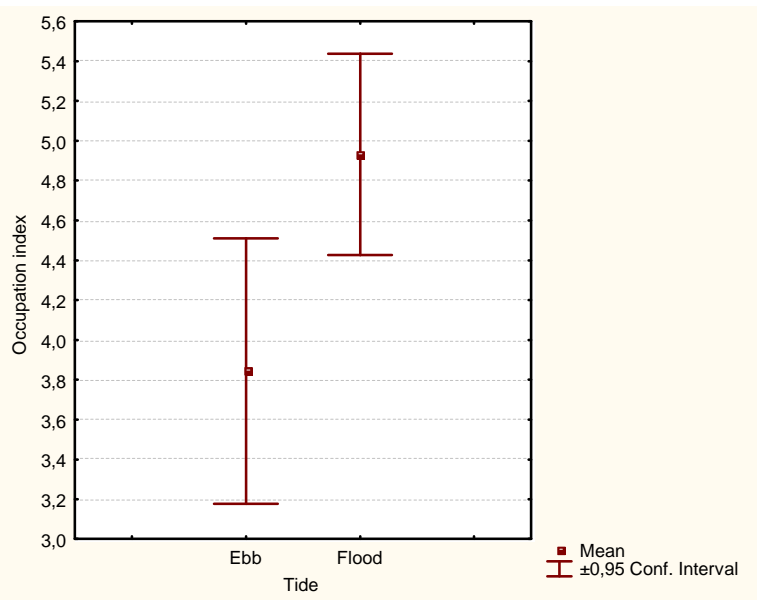

Figure 4 - Sotalia guianensis occupation index variation in São Francisco do Sul harbor inlet along tide variation. 


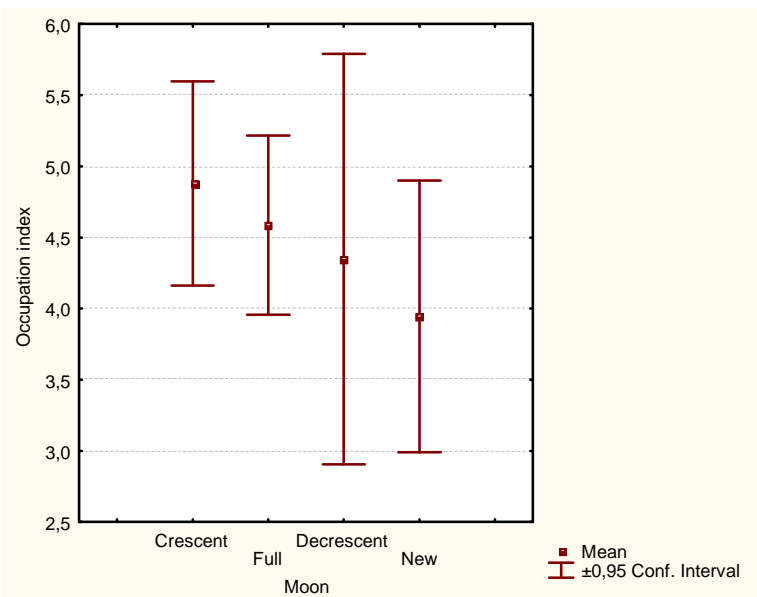

Figure 5 - Sotalia guianensis occupation index variation in São Francisco do Sul harbor inlet along moon phases.

The main inlet entrance route of the dolphins was from the south and southwest direction, so as the leaving route. Many times the entrance was in fast traveling, followed by an intense fishing activity, and apparently the dolphins had detected the prey distantly. The dolphins never arrived the inlet from north or northeast directions that corresponded to the entrance channel.
In the inlet, the main area used by the dolphinsas the vicinity of the attracted charge ships where the dolphins fished actively, sometimes showing a characteristics' fishing movement. The dolphins grouped the fish schools in the central portion of the inlet and conducted them in the direction of the ships, using them as a barrier for catch facilitation. In the ships vicinity it was common to see dolphins jumping with fishes in the mouth (Fig. 6).

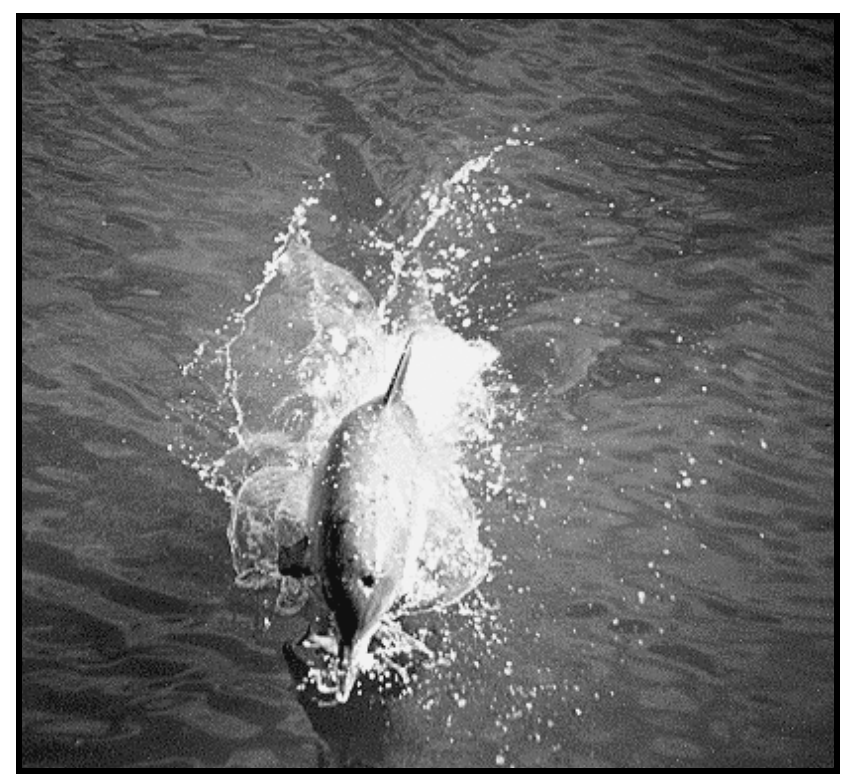

Figure 6 - Sotalia guianensis jumping near a ship with a fish in the mount. 
In general, the dolphins went away temporally from the area during ship movement, returning soon after. Although an intense fishing activity was observed at times in the inlet after the ship passage. Considering that the ships moved the bottom sediment when passed, leaving the water turbid, probably the preys that were in the bottom became displaced and disoriented becoming easier to catch. The dolphins also fished intensively in the ship places after they left the harbor.

\section{Time budget}

The predominant inlet behavior was fishing, followed by traveling $[\mathrm{H}(3, \mathrm{~N}=30)=19.448 ; \mathrm{p}=$ $0.0002<0.05$ )] (Fig. 7).

\section{Group size and composition}

The mean group size of $S$. guianensis in the inlet was of four individuals (Table 1).

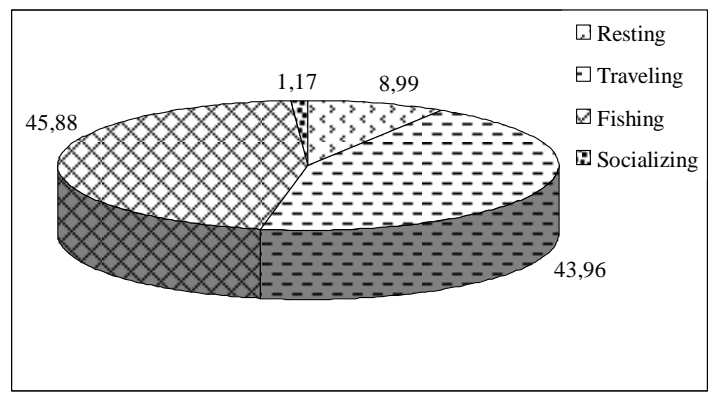

Figure 7 - Time budget for behavioral pattern sampled in São Francisco do Sul harbor inlet between January and June 1998.

Table 1 - Sotalia guianensis group size and composition in São Francisco do Sul harbor inlet during January and June 1998.

\begin{tabular}{lccc}
\hline Parameters & Adults & Calves & Group \\
\hline Mean & 3.68 & 0.43 & 4.11 \\
$\mathrm{SD}$ & 2.46 & 0.61 & 2.71 \\
Mode & 2 & 1 & 2 \\
$\mathrm{~N}^{\mathrm{o}}$ minimum & 1 & 0 & 1 \\
$\mathrm{~N}^{\mathrm{o}}$ maximum & 18 & 3 & 18 \\
\hline
\end{tabular}

Although there were groups of 18 individuals, group division was very common when they approached the ships in inlet, forming smaller groups, in general with two individuals (= mode). In the same way, when the groups escaped from he inlet, there was a tendency to form larger groups.

\section{DISCUSSION}

The harbor inlet occupation by $S$. guianensis population showed to be very intense, considering the Babitonga bay size $\left(=160 \mathrm{~km}^{2}\right)$ and good conservation status of a large part of the bay. The observations showed that the population used the harbor inlet with fishing purposes. This habitat use pattern seemed that of other dolphin species, like the Hector's dolphin, Cephalorhynchus hectori (Bejder and Dawson, 2001), the atlantic whitesided dolphin (Selzer and Payne, 1988) and the bottlenose dolphin, (Wursig and Wursig, 1979; Gubbins, 2002). The harbor inlet constitutes an artificial environment in the bay and the population learned to use its structure for prey catch, supporting the intrinsic perturbations of the harbor activity. One possibility was that the animals became habituated with the activities of the area along the more than 40 years of the establishment of the harbor in this region. Studies on cetacean habitat use have shown that the environmental parameters showed a significant influence on the inlet occupation by the dolphins (Wells et al., 1980; Shane et al., 1986; Selzer and Payne, 1988; Acevedo-Gutiérrez and Parker, 2000). However, in this case, it is possible that the 
environmental parameters influenced mainly the prey movement. Tide movement is an important variable in fish movement in estuarine areas. Although our results do not indicated a relation between moon phases and occupation index, moon phases are directly associated to tide level and movement, and so affect the fish movement (Gibson, 1999). Fishes movement is also influenced by the seasons, with the occurrence of migration events. May, which corresponded to the month of highest inlet occupation, was the period of Mugilidae species migration along the south coast, inside estuarine areas (Menezes and Figueiredo, 1985). Mugil spp. are part of $S$. guianensis diet in Babitonga bay population (Marcucci and Cremer, 2004). The harbor inlet, positioned in the bay entrance channel, can be an important area of concentration of this species. Thus, cetacean distribution and abundance are associated to the oceanographic characteristics from a region connected directly to the food chain. Although few observations were made regarding the socializing behaviors, during naturalistic observations conducted on the ships board, court and sexual behaviors beside the ships were observed in one occasion [for more details see Cremer (2000)]. Moreover, calves were constant in the area, in spite of ships movement and noise pollution that possibly reflected the population habituation.

Feeding was the most common behavior in the area that reflected the specific purpose of the population for the inlet occupation. Feeding was also the most frequent behavior observed for $S$. guianensis population in Norte bay, Santa Catarina (Daura-Jorge et al., 2005), Paraty bay, Rio de Janeiro (Lodi, 2003), north coast of Rio de Janeiro (Di Beneditto et al. (2001), and in Cispatá bay, in Colombian Caribbean coast (García and Trujillo, 2004). Analyzing the Babitonga bay, Cremer (2000) observed that traveling was the most frequent behavior pattern for the population, so as observed by Bonin (2001) in Guaraqueçaba bay, Paraná, Geise et al. (1999) in Cananéia estuary, São Paulo, and Pereira (1999) in Sepetiba bay, Rio de Janeiro.

Sotalia guianensis harbor inlet groups tended to be smaller than that groups occurring in the Babitonga bay in general (Cremer, 2000), probably because of the typical behavior showed in the area that was fishing. S. guianensis groups varied between one to 30 individuals, and groups between two and six individuals were the most common (Simões-Lopes, 1988; Geise, 1991; Carr and Bonde, 2000; Bonin, 2001; Torres and Beasley, 2003; García and Trujillo, 2004; DauraJorge et al., 2005).

Cetacean coastal species are more threatened by the antropic impacts, considering the intense use of their habitats for development of human activities. Although S. guianensis is considered a shy species that avoid motor boats (Silva and Best, 1994; Santos et al., 2001), its long time occurrence in some environments that suffer a significant impact, such as Guanabara bay (Rio de Janeiro) (Geise, 1991), Babitonga bay (Santa Catarina) (Cremer, 2000) and Baía Norte (Santa Catarina) (Flores, 1999; Wedekin et al., 2005), for example, indicated that the species presented a considerable tolerance level to antropic perturbations. However, as observed for other coastal cetacean species, impact intensity might lead to other impacts in a medium and long time (Martineau et al., 1988; Richardson et al., 1995).

Impacts resulting from boats have been reported in the literature and are mainly associated to tourism activities (dolphin-watching) (Lusseau, 2003). Foote et al. (2004) observed significant changes in orca, Orcinus orca, communication associated with the increase in pollution caused by the boats noise. Instead, this behavioral flexibility could also bring negative consequences to population survival. In the case of coastal dolphins, adaptation associated to remain in highly impacted environments can result in high contamination indexes, related with the discharge of effluent containing heavy metals and organochlorides. This kind of pollution can cause many kinds of tumours (Geraci et al., 1987) and/or epidermal lesions associated with a disease (Wilson et al., 2000). São Francisco do Sul harbor inlet had a high pollution level, both in water as in sediment, a consequence of the contaminants apport from the estuarine system, which was impacted not only by the industrial activities, but also from the harbor activity adding oil and grease residues, antifowling paintings and granel charge (Tureck, 2002). The reduction of beluga, Delphinapterus leucas, population in Canada was directly related to a high pollutant level, mainly organochlorides, identified in animals' tissue (Martineau et al., 1988). Besides the chemical pollution, the noise pollution can be very dangerous. The maintenance of dolphin populations in areas with a high noise level can produce irreversible damage to the ear 
apparatus, reducing individual's hear acuity (Richardson et al., 1995). However, more studies are necessary to verify the population dynamic in these areas in a medium and long time. In regions so as in Adriatic Sea, the low density of $T$. truncatus and the disappearance of short-beaked common dolphin, Delphinus delphis, were associated to habitat quality reduction (Bearzi et al., 2004).

The continuity of $S$. guianensis research in this area after the period of the present work showed a drastic change from 1999. During this year, the harbor suffered enlargement repairs, using drags and pile-drivers, so as other heavy machines, promoting and intense perturbation in the area. From 1999 to the recent observations (2006), the dolphins did not enter the inlet, so as in the São Francisco do Sul city vicinity (behind the harbor), where they were frequently observed by the local people and tourists (Cremer et al., 2004). The anterior inlet occupation index and the total abandonment of this area by the dolphins, showed a clear example of the potential impact of human activities in cetacean habitat use, including the habitat leaving. Although S. guianensis could be considered a species with a significant tolerance degree in relation to human activities, in this case the limits of tolerance were aimed.

\section{ACKNOWLEDGMENTS}

This work was supported by the National Council of Research and Development (Conselho Nacional de Pesquisa e Desenvolvimento) - CNPq (Master Fellowship), and Natural Resources and Ecology Graduation Program of São Carlos Federal University (Programa de Pós-Graduação em Ecologia e Recursos Naturais of Universidade Federal de São Carlos). Financial support was also given by the Fundação $O$ Boticário de Proteção à Natureza and logistic support was given by the local administration of São Francisco do Sul. The study continuity was financially supported by from the Research Support Fund (Fundo de Apoio à Pesquisa) of the Universidade da Região de Joinville (FAP-UNIVILLE).

\section{RESUMO}

Os padrões de ocupação da enseada do porto de cargas de São Francisco do Sul, no interior da Baía da Babitonga, sul do Brasil, pela população de botos cinza Sotalia guianensis foi estudada entre setembro/1996 e junho/1998. Totalizou-se 200 horas de observações naturalísticas e 141.2 horas de observação sistemática na área, utilizando-se binoculares 7 x 50. Foram registrados a cada intervalo de 3 minutos dados sobre o número de indivíduos presentes e comportamento. A população utilizou intensamente a enseada do porto, principalmente para atividades de pesca. A maré enchente foi responsável por maiores taxas de ocupação. Dentre os meses analisados, maio foi o mês com maior média nas taxas de ocupação, e janeiro o mês de menor ocorrência. O tamanho de grupo médio na área foi de quatro indivíduos.

\section{REFERENCES}

Acevedo-Gutiérrez, A. and Parker, N. (2000), Surface behavior of bottlenose dolphin is related to spatial arrangement of prey. Mar. Mamm. Sci., 16, 287-298.

Altmann, J. (1974), An observational study of behavior: sampling methods. Behaviour, 4, 227-267.

Ballance, L. T. (1992), Habitat use patterns and ranges of bottlenose-dolphin in the Gulf of California, Mexico. Mar. Mamm. Sci., 8, 262-274.

Bearzi, G.; Holcer, D. and Notarbartolo di Sciara, G. (2004), The role of historical dolphin takes and habitat degradation in shaping the present status of northern Adriatic cetaceans. Aq. Conserv. Mar. Fresh. Ecosyst., 14, 363-379.

Bejder, A. and Dawson, S. (2001), Abundance, residence, and habitat utilization of hector's dolphins (Cephalorhynchus hectori) in Porpoise Bay, New Zealand. New Zealand J. Mar. Fresh. Res., 33, 277287.

Bonin, C. A. (2001), Utilização de habitat pelo botocinza, Sotalia fluviatilis guianensis (Cetacea, Delphinidae), na porção norte do complexo estuarino da Baía de Paranaguá, PR. Master Thesis, Universidade Federal do Paraná, Curitiba, Brazil.

Carr, T.; Bonde, R. K. (2000), Tucuxi (Sotalia fluviatilis) occurs in Nicarágua, $800 \mathrm{~km}$ of its previously known range. Mar. Mamm. Sci., 16, 447452. 
Clemmons, J. R. and Buchholz, R. (1997), Linking conservation and behavior. In - Behavioral approaches to conservation in the wild, ed. J. R. Clemmons and R. Buchholz. University Press, Cambridge, pp. 23-47.

Cremer, M. J. (2000), Ecologia e Conservação de Sotalia fluviatilis guianensis (Cetacea, Delphinidae) na Baía de Babitonga, litoral norte de Santa Catarina. Master Thesis, Universidade Federal de São Carlos, São Carlos, Brazil.

Cremer, M. J.; Hardt, F. A. S.; Tonello Júnior, A. J.; Simões-Lopes, P. C. and Pires, J. S. R. (2004), Core areas changes in Sotalia guianensis (Cetacea, Delphinidae) population in Babitonga bay, Santa Catarina. Revta. Univille, 9, 130-134.

Daura-Jorge, F. G.; Wedekin, L. L.; Piacentini, V. Q. and Simões-Lopes, P. C. (2005), Seasonal and daily patterns of group size, cohesion and activity of the estuarine dolphin, Sotalia guianensis (P.J. van Bénéden) (Cetacea, Delphinidae), in southern Brazil. Revta. bras. Zool., 22, 1014-1021.

Di Beneditto, A. P. M.; Ramos, R. M. A. and Lima, N.R.W. (2001), Sightings of Pontoporia blainvillei (Gervais and D'Orbigny, 1844) and Sotalia fluviatilis (Gervais, 1853) (Cetacea) in South-eastern Brasil. Braz. Arch. Biol. Tech., 44 (3), 291-296.

Edwards, H. H. and Schnell, G. D. (2001), Status and ecology of Sotalia fluviatilis in the Cayos Miskito Reserve, Nicaragua. Mar. Mamm. Sci., 17, 445-472.

Flores, P.A.C. (1999), Preliminary results of a photoindentification study of the marine tucuxi, Sotalia fluviatilis, in southern Brazil. Mar. Mamm. Sci., 15, 840-847.

Flores, P. A. C. and Bazzalo, M. (2004), Home range and movement patterns of the marine tucuxi dolphin, Sotalia fluviatilis, in Baía Norte, southern Brazil. Lat. Am. J. Aq. Mamm., 3, 37-52.

Foote, A. D.; Osborne, R. W and Hoelzel, A. R. (2004), Whale-call response to masking boat noise. Nature, 428, 910.

García, C. and Trujillo, F. (2004), Preliminary observations on habitat use patterns of the marine tucuxi, Sotalia fluviatilis, in Cispatá Bay, Colombian Caribbean coast. Lat. Am. J. Aq. Mamm., 3, 53-60.

Geise, L. (1991), Sotalia guianensis (Cetacea, Delphinidae) population in the Guanabara Bay, Rio de Janeiro. Mammalia, 55, 371-379.

Geise, L.; Gomes, N. and Cerqueira, R. (1999), Behaviour, habitat use and population size of Sotalia fluviatilis (Gervais, 1853(Cetacea, Delphinidae) in the Cananéia estuary region, São Paulo, Brazil. Revta. Bras. Biol., 59, 183-194.

Geraci, J. R.; Palmer, N. C. and St. Aubin, D. J. (1987), Tumours in cetaceans: analysis and new findings. Can. J. Fish. Aquat. Sci., 44, 1289-1300.

Gibson, R. N. (1999), Movement and homing in intertidal fishes. In - Intertidal fishes. Life in two words, ed. M. H. Horn; K. L. M. Martin and M. A. Chotkowski. Academic Press. London, pp. 97-125.

Gubins, C. (2002), Use of home ranges by resident bottlenose dolphins (Tursiops truncatus) in south Carolina Estuary. J Mammalogy, 83, 178-187.

Hardt, F. A. S. (2005), Padrões de residência do golfinho Sotalia guianensis (Cetacea, Delphinidae) na Baía da Babitonga, litoral norte de Santa Catarina. Master Thesis. Universidade Federal do Paraná, Curitiba, Brazil.

Lodi, L. (2003), Seleção e uso de habitat pelo botocinza, Sotalia guianensis (Van Bénéden, 1864) (Cetacea, Delphinidae), na Baía de Paraty, estado do Rio de Janeiro. Bioikos, 17, 5-20.

Lusseau, D. (2003), Effects of tour boats on the behavior of bottlenose dolphins: using Markov chains to model anthropogenic impacts. Cons. Biol., 17, $1785-1793$.

Marcucci, A. and Cremer, M. J. (2004), Estudo da ecologia alimentar de Sotalia guianensis (Cetacea, Delphinidae) e Pontoporia blainvillei (Cetacea, Pontoporiidae) na região da Baía da Babitonga, Santa Catarina, Brasil. Cad. Inic. Pesq., 5, 51-59.

Martineau, D.; Laglace, A.; Beland, P.; Higgins, R.; Armstrong, D. and Shugart, L.R. (1988), Pathology of stranded beluga whales (Delphinapterus leucas) from St. Lawrence estuary, Quebec, Canada. J. Comp. Pathol., 98, 287-311.

Menezes, N. A. and Figueiredo, J. L. (1985), Manual de peixes marinhos do sudeste do Brasil V. Teleostei (4). Museu de Zoologia, Universidade de São Paulo: São Paulo.

Norris, K. S. and Dohl, T. P. (1980), The structure and functions of cetacean schools. In - Cetacean behavior: mechanisms and functions, ed. L.M. Herman. John Wiley and Sons, New York, pp. 211261.

Pereira, T. C. C. L. (1999), Estudo da dinâmica de uso do habitat da Baía de Sepetiba (RJ) pelo boto-cinza Sotalia fluviatilis (Cetacea, Delphinidae). Master Thesis. Universidade Federal Rural do Rio de Janeiro, Seropédica, Brazil.

Pizzorno, J. L. A. (1999), Estimativa populacional do boto-cinza, Sotalia fluviatilis, na Baía de Guanabara, por meio de catálogo de fotoidentificação. Master Thesis. Universidade Federal Rural do Rio de Janeiro, Seropédica, Brazil.

Primack, R. B. and Rodrigues, E. (2001), Biologia da Conservação. Efraim Rodrigues, Londrina.

Richardson, W. J.; Greene, C.R.Jr.; Malme, C.I. and Thomson, D. H. (1995), Marine mammals and noise. Academic Press, San Diego.

Santos, M. C. O.; Acunã, L. B. and Rosso, S. (2001), Insights on site fidelity and calving intervals of the marine tucuxi dolphin (Sotalia fluviatilis) in southeastern Brazil. J. Mar. Biol. Ass. U. K., 81, 1-4. 
Selzer, L. A. and Payne, P. M. (1988), The distribution of white-sided (Legenorhynchus acutus) and common dolphins (Delphinus delphis) vs. environmental features of the continental shelf of the northeastern United States. Mar. Mamm. Sci., 4, 141-153.

Shane, S. H. (1990), Behavior and ecology of the bottlenose dolphin at Sanibel Island, Florida. In-The bottlenose dolphin, ed. Academic Press, San Diego, pp. 245-265.

Shane, S. H.; Wells, R. S. and Würsig, B. (1986), Ecology, behavior and social organization of the bottlenose dolphin: A review. Mar. Mamm. Sci., 2, 34-63.

Silva, V. M. F. and Best, R. C. (1994), Tucuxi Sotalia fluviatilis (Gervais, 1853). In-Handbook of Marine Mammals, ed. S.H. Ridgway and S.R. Harrison. Academic Press, London, pp. 43-69.

Simão, S. M.; Pizzorno, J. L. A.; Perry, V. N. and Siciliano, S. (2000), Aplicação da técnica de fotoidentificação do boto-cinza Sotalia fluviatilis (Cetacea, Delphinidae) da Baía de Sepetiba. Floresta e Ambiente, 7, 31-39.

Simões-Lopes, P. C. (1988), Ocorrência de uma população de Sotalia fluviatilis Gervais, 1853, (Cetacea, Delphinidae) no limite sul de sua distribuição, Santa Catarina, Brasil. Biotemas, 1, 5762.

Torres, D. and Beasley, C. R. (2003), Pattern of use of a small bay in northern Brazil by Sotalia guianensis (Cetacea: Delphinidae). Amazoniana XVII, 3, 583594.
Tureck, C. R. (2002), Avaliação do crescimento e contaminação em Crassostrea gigas (Molusca, Bivalve) cultivadas na Baía da Babitonga, Santa Catarina. Master Thesis. Universidade da Região de Joinville, Joinville, Brazil

Wedekin, L. L.; Da-Ré, M. A.; Daura-Jorge, F. G. and Simões-Lopes, P.C. (2005), O uso de um modelo conceitual para descrever o cenário de conservação do boto-cinza na Baía Norte, Sul do Brasil. Natureza and Conservação, 3, 59-67.

Wedekin, L. L.; Daura-Jorge, F. G.; Piacentini, V.Q. and Simões-Lopes, P.C. (in press), Seasonal variations in spatial usage by the estuarine dolphin, Sotalia guianensis (Cetacea, Delphinidae) at its southern limit of distribution. Braz. J. Biol.

Wells, R. S., Irvine, A. B. and Scott, M. D. (1980), The social ecology of inshore odotocets. In-Cetacean behavior: mechanisms and functions, ed. L. M. Herman. John Wiley, New York, pp. 263-317.

Wilson, B.; Grellier, K.; Hammond, P.; Brown, G. and Thompson, P.M. (2000), Changing occurrence of epidermal lesions in wild bottlenose dolphins. Mar. Ecol. Prog. Ser., 205, 283-290.

Würsig, B. and Würsig, N. (1979), Behaviour and ecology of the bottlenose dolphin, Tursiops truncatus, in the south Atlantic. Fish. Bull., 77, 399-412.

Received: May 25, 2006; Revised: March 23, 2007; Accepted: August 18, 2008. 